DOI : $10.24260 /$ khatulistiwa.v8i2.1168

\title{
CHARACTER REINFORCEMENT OF SOCIAL CARE THROUGH PULUANG TRADITION IN WAJOK HILIR VILLAGE, MEMPAWAH
}

\author{
Tuti Alawiyah
}

Pontianak Institute of Islamic Studies

Email: tutialawiyah814@gmail.com

\section{HIGHLIGHT}

- Puluang Tradition

- Islam and Local Culture

- Overseas Bugis Culture

\begin{abstract}
Social care is an achievement outside of itself to help others or others through positive actions, eagerness, full of meaning and relationships that bind the community together. The mutual cooperation activities can be found in the people's life of Wajok Hilir Village. This area is urban areas, located in Mempawah Regency. This community is a village that has a majority of Bugis migrant from Sidendreng residents, Makasar. Puluang Tradition is a cultural custom that is still carried out by the Bugis tribe in Wajok Hilir Village. In tradition this usually occurs in an activity such as farming, marriage and building a new home. The tradition is full of social caring character values, such as being light-hearted, diligent, collaborating, having cooperation and being reciprocated.
\end{abstract}

Keywords:

Puluang Tradition, Bugis Migrant, Wajok Hilir, Mempawah
KHATULISTIWA: Journal of Islamic Studies Vol. 8, No. 2. September 2018
DOI: $10.24260 /$ khatulistiwa.v8i2.1168

Character Reinforcement of Scoial Care Through Puluang Tradition in Wajok Hilir Village Mempawah 


\section{A. INTRODUCTION}

Social care is a way in preserving relationship with others. Besides, Tronto (1993) defines care is an achievement towards something outside theirselves. Care is also related with eagerness, positive, meaningfull, and relationship (Phillips, 2007). Social care is a nature condition of human species and tools tighten community in togetherness (Adler, 1927:72 in Sugiyarbini 2012). Noddings (2002) mentioned that if we care to others, we will respond positively what the people's need and express as an action. So that, social care is an achievement from outside themselves to help others or people through positive action, warming, menaningfull and tightening relation of community in togetherness.

Social caring character needs to be built since early childhood age. Parent's knowledge about the importance in building social care to the children will determine the children character in the future, whether the children will have caring personality towards their social environment or to be careless person towards their social environment. In line with the developing age, social caring values keeps on degradation particularly in teenagers or students. For example, careless, want to be the only winner, unfriendly, etc. The cause of those degradation are vary, such as social distance or social status, egoisme, lack of understanding or lack of social caring values building, lack of tolerant, sympathy and empathy.

Hendra Kurniawan (2013) assessed the fade of social caring sense is not only tend to the ordinary people. Politically, social attitude can be seen from the leader actions who are more interested with their own interests than their people's interests. It is not a secret if the politicians in this country do the corruption in congregation without any guilty and shame. Corruption is sistemized, moreover by regional autonomy system, so that the corruption is getting wider regionally. Beside the current corruption issues and social careless of society to others, people in Wajok

KHATULISTIWA: Journal of Islamic Studies Vol. 8, No. 2. September 2018
DOI: 10.24260/khatulistiwa.v8i2.1168

Character Reinforcement of Scoial Care Through

Puluang Tradition in Wajok Hilir Village

Mempawah 
Hilir, Parit Langgar can preserve the culture existance of mutual helping each others through Puluang culture. How is Puluang tradition occur in Wajok Hilir Village, Parit Langgar? What are the character values of social care put in Puluang tradition?

Based on the background above, this study aims to describe how Puluang tradition occur in Wajok Hilir Village, Parit Langgar is; and what the character values of social care put in Puluang tradition are.

\section{Character Reinforcement}

Simply character is defined as an attitude or behavior attached to somebody. So, it can be said that character is one's personality. In Indonesia, character means positive attitudes or characterstics.

Because of these positive meaning of character, it showed the term of character reinforcement through education. Then, it has been introduced the term of character education.

Abudin Nata (2014: 315) stated that literally character education can be interpreted by change or build someone's nature, behavior, temperament, personality and character based on certain criteria. "Character education is an effort to educate one's behavior become better so this better character can build a qualified generation for nation". While Mujid (2000: 36-39) essentially education character as an effort to help children growth mentally and physically, from their nature become better human civilization".

Hornby and Parnwell, (1972: 49) in Abdul Majid (2011) the definition of character is mental or moral quality, name and reputation. Hermawan Kenjaya (2010: 3) in Abdul Majid (2011) defines character is a particular character belongs to thing or person.This particular characteristic is innate and based on thing and person identity. It is also as the 'driving' machine how a person should act, behave, say, and respond something.

KHATULISTIWA: Journal of Islamic Studies Vol. 8, No. 2. September 2018
DOI: $10.24260 /$ khatulistiwa.v8i2.1168

Character Reinforcement of Scoial Care Through

Puluang Tradition in Wajok Hilir Village

Mempawah 
Hidayatullah (2010: 13) stated that character is mental or moral quality or strength and person's akhlaq or good character as a particular character that become the driven to differenciate one to others. A person can be said having a good character if the person can get the value or belief from people's demand and it is used as a moral strength in the person's life.

One of the weaknesses of Indonesia is character building. So that, it is a positive action of government (Mendikbud) to apply character building in all degrees of education. Through character building, it is hoped that this nation will be a dignified nation, having additional value, and selling point offered to others and other nations in the world, so that we can compete with other nations in global market (Mulyasa, 2012: 8).

\section{B. METHOD}

This research is using descriptive study. The researcher describes the culture or tradition of Puluang in Wajok community, particularly the descendant of Bugis community.

Data are collected from interview with community's figure or elder people who can describe the tradition well. It is not difficult to find these figures or elder people who can describe and tell to the researcher about the tradition because its tradition lives and occurs in Wajok commnity since nowadays.

Besides the reseracher's experiences as the part of Wajok community, who born and grew in Wajok, can be used as a need analysis in this study. Although, the researcher is not involved directly in this tradition, the researcher can compare the observation and interview result.

After collecting the data, the researcher discusses it through character building perspective. The result of discussion is divided in to two; data description and analysis.

KHATULISTIWA: Journal of Islamic Studies Vol. 8, No. 2. September 2018
DOI: $10.24260 /$ khatulistiwa.v8i2.1168

Character Reinforcement of Scoial Care Through

Puluang Tradition in Wajok Hilir Village

Mempawah 


\section{RESULT AND DISCUSSION}

\section{Wajok Hilir Village}

Wajok Hilir village is in urban area, located in Mempawah region, West Kalimantan province, directly adjacents with Purun. It is for about an hour in travelling from Wajok Hilir to Pontianak.

Wajok Hilir village contains of few villages; they are Parit Wa'dokkak, Parit Langgar, and Parit To'adam. Observation and data collecting point is Parit Langgar.

The name of Parit Langgar comes from Parit and Langgar based on the history. It is called Parit because there is parit (creek) in this village and it is called langgar (a prayer place) because there is the mosque of Al Falah in this village. The community called the mosque as langgar. So that, the vilage is called Parit Langgar.

There are many various tribes live in this village. The majority tribe who live in this village is Bugis Sidendreng. Bugis Sidrendeng tribe is settled entrants because they married with the native people there. This migration is the beginning of the term Bugis Sidrendeng. This is because there is a village namely Sidrendeng village in South Sulawesi. People of Sidrendeng village is the entrants in Wajok Hilir when Indonesia was colonized by Dutch in 1930. Based on Dayak people as the first people live in Wajok Hilir, the entrants said that they came from Sidrendeng village. Therefore, the entrants are called Bugis Sidrendeng. They are majority tribes in Chinese, Javanese, and Malay.

The people in Parit Langgar are moslem such as Bugis, Javanese and Malay. While a few Dayak people are muallaf (person embraces Islam recently) because they married Bugis people and a few Dayak people are Konghucu because they married with Chinese. Chinese people embrace 70\% Congfucians and 30\% Protestant Christian.

KHATULISTIWA: Journal of Islamic Studies Vol. 8, No. 2. September 2018
DOI: 10.24260/khatulistiwa.v8i2.1168

Character Reinforcement of Scoial Care Through

Puluang Tradition in Wajok Hilir Village

Mempawah 
The people work as farmers, merchants, civil servants, and rubber farmers. Rubber farmer is their long-term job but now their lands are planted by plam oil trees. Moreover, there are many big palm oil factories around their village. The people who do not have wide land, they work as labors. The labors are mostly young adult from the village.

\section{Tradition of Puluang}

Puluang is a tradition is carried out by Bugis people in Wajok Hilir village since 1960. It was is carried out by their ancestors who have duties in their village. Teachers and elders are commonly famous people in their village, so the students/the people will reply their services with many things such as planting fields, building houses, making altars, etc. The word 'Puluang' means a mutual help or work together in doing social charity work. Once, it is only used to help famous people, but now it used to help others. For instance, in the marriage party of A, A is never asks B's help, eventhough they do not have any family relationship. When B is announced and is carried out a family event, A will help B with making an altar.

Puluang tradition usually apply in many events such as planting fields, marriage, and building a new house. Recently, Puluang tradition in planting fields is leaving, it is replaced by Belalek tradition. From Belalek's name, it can be said that it is influenced by Malay Sambas and Kayatan cultures. (Yusriadi, 2016; Johansen, dkk, 2018).

Related with Puluang tradition in marriage, this tradition is still exist among the society. This tradition exists in marriage party when the host make marriage tents or altars.

When the host rents the tents and altars, it means that this tradition is not is carried out because all preparation starts from delivering and decorating the tents are is carried out by the tent's owner.

KHATULISTIWA: Journal of Islamic Studies Vol. 8, No. 2. September 2018
DOI: 10.24260/khatulistiwa.v8i2.1168

Character Reinforcement of Scoial Care Through Puluang Tradition in Wajok Hilir Village Mempawah 
Puluang tradition is still is carried out in building house but it is only in occasion. Besides those factors, this tradition is is carried out because host and families gathering by saying "melok puluang alena" means the host needs help.

This is Puluang tradition in building houses procession. Before Puluang procession, the host called mak duppa invites people around or near his/her house. The invitation sometimes done by a boy, a teenager, wearing formal costumes, using trousers and kopia (hat). The boy says "(host's name) sends greeting that there is Barsanji after Isya pray to build a new house". The elders are invited and lead Barsanji. Finally, host gives the people some meals and the procession is finish after they eat the meals.

Puluang is occured at 7 o'clock in the morning. People who want to help gather in host's house. They are served by some meals such as ketupat, soybean cake fried spicy, and some coffee or tea. Then, they build a pillar of the house. Puluang usually finishes at 10 o'clock. The wide of the house is also influenced the time. If Puluang has not finished yet at noon, the host obligates to prepare some lunch for the people. After building a pillar finishes, the people who help the host go back to their houses and the host gartitudes them.

Puluang in building a tent or altar is different with building a house. In building a tent or altar, the invitation sends from person to person directly. People who hear the invitation can conclude by themselves that in three or four days later before the marriage party, there is building a tent or altar. If the marriage party will be is carried out on Sunday so Puluang will be hel on Wednesday or Thursday.

Because of the host invitation, so Puluang must be is carried out as the obligation as a member in the community. If people can not join Puluang, they will get social punishment from the community such as being a gossip, unsocialize, can be

KHATULISTIWA: Journal of Islamic Studies Vol. 8, No. 2. September 2018
DOI: 10.24260/khatulistiwa.v8i2.1168

Character Reinforcement of Scoial Care Through

Puluang Tradition in Wajok Hilir Village

Mempawah 
excommunicated in this Puluang tradition. Moreless, the people will not help them, when they need some help.

Eventhough Puluang is the obligation of people, this event does not bind people. The people who have other activities can participate in a few moment or they can participate when their other activities have been finished.

If the people can not participate, they can send their repalcement people to participate such as their daughters or their wife to help the host. The daughters and wifes participate in cooking some meals and preparing kitchen logistics.

Puluang tradition is is carried out in the morning at 8 o'clock until it finishes. If it finishes before lunch, the host must prepare some lunch. The lunch usually Cendol porridge. Cendol porridge is economically choosen because it is easy to be made and the ingredients are easy to find even in their own garden.

If the work is harder and takes many times, the host must consider to give the people some meals and it is not only just Cendol prorridge.

In Puluang tradition, it is not only for men but also women can participate this tradition. The women help to prepare some meals in the kitchen for the men. It is not only married people but also young adult can participate in this tradition.

\section{Values of Social Caring Character in Puluang Tradition}

There are many values of Puluang tradition in Parit Langgar. First, helpful. Mutual help means togetherness but it is a part of individual consideration sense of helping people.

Second, dilligent. The community attendance in Puluang event reflects the social life. It tights the relation among community. The people are doing gathering, chatting, and talking. It is because the majority of their profession are farmers who rarely doing gathering without any other activities is carried out in the community.

KHATULISTIWA: Journal of Islamic Studies Vol. 8, No. 2. September 2018
DOI: 10.24260/khatulistiwa.v8i2.1168

Character Reinforcement of Scoial Care Through

Puluang Tradition in Wajok Hilir Village

Mempawah 
Third, cooperate. The cooperation among the community in mutual help will make anything easy and can be finished together. Moreover, village communities are identically friendly and polite to others. A lot of jobs can be finished quickly because of the cooperation among people. The people work together with their own abilities such as lifting woods, binding a pillar, etc.

Fourth, building togetehrness. Puluang is an action done by many people. The togetherness will be built among the people well. The togetherness is not only measured by the event at that time but also for the future activities.

Fifth, returning the favor. Although mutual help is volunteer activity but this activity is actually returning the favor. The people returns the favors each other so it can not be known who are the first and the last people return the favor. Puluang tradition binds the member of community to return or remind the kindness of the people in the community.

Puluang is the important part in growing the attitude for the daily life. For instance, beside Puluang activities mentioned above, the people also do mutual help in healing sick people for who can heal them and the sick people will pay with their ability by seeing the needs of the helper.

Puluang in Parit Langgar and Wajok community is one of the examples that in this fast and uncontrolled globalization era, there are many communities that still preserve social caring value in the community.

\section{CONCLUSION}

Puluang tradition is mutual help tradition in planting fields, marriage, and building a pillar of a new house. In the overseas Bugis people in Wajok Mempawah, this tradition is their heritage. It is is carried out crossed ethnicity means that it is not only Bugis but also other tribes do this Puluang.

KHATULISTIWA: Journal of Islamic Studies Vol. 8, No. 2. September 2018
DOI: $10.24260 /$ khatulistiwa.v8i2.1168

Character Reinforcement of Scoial Care Through

Puluang Tradition in Wajok Hilir Village

Mempawah 
Puluang is is carried out to help others in Wajok community particularly in Parit Langgar. This mutual help becomes the obligation of community in social life particularly in neighborhood life. It is not possible if people can live without others.

There are building character values of Puluang tradition in Wajok Hilir. They are helpful, dilligent, any abilities can be applied, easy and finish quickly, cooperation among people because the people do not have the same ability, tight the realation among the people and saving the expenses.

KHATULISTIWA: Journal of Islamic Studies Vol. 8, No. 2. September 2018
DOI: 10.24260/khatulistiwa.v8i2.1168

Character Reinforcement of Scoial Care Through Puluang Tradition in Wajok Hilir Village Mempawah 


\section{BIBLIOGRAPHY}

Abdul, M. (2000).Fitrah dan Kepribadian Islam Sebuah Pendekatan Psikologis. Jakarta: Darul Falah.

Nata, A. (2014). Akhlak Tasawuf dan Karakter Mulia. Jakarta: Rajawali Pers,. cet. 1.

Furqon,H,.(2010). Pendidikan Karakter Membangun Peradaban Bangsa. Surakarta: Yuma Pustaka.

Majid, A \& Andayani.(2011). Pendidikan Karakter Perspektif Islam. PT. Remaja Rosdakarya.

Mulyasa. (2012). Manajemen Pendidikan Karakter. Jakarta: Bumi Aksara.

\section{INTERVIEWEES}

Abdul Muin Haddad, (65 years old), Wajok.

Syahbandi (33 years old), Wajok.

Farina (30 years old), Wajok

KHATULISTIWA: Journal of Islamic Studies Vol. 8, No. 2. September 2018
DOI: 10.24260/khatulistiwa.v8i2.1168

Character Reinforcement of Scoial Care Through Puluang Tradition in Wajok Hilir Village Mempawah 